\title{
TREE DIVERSITY IN HOMEGARDEN LAND USE OF MAWSMAI VILLAGE KARST LANDSCAPE, MEGHALAYA, NORTHEAST, INDIA
}

\section{BSHAR SAMIR BDOOR}

School of Environmental Sciences, Jawaharlal Nehru University, New Delhi, India

\begin{abstract}
Loss of biodiversity is one of the most pressing environmental concerns of our time. This study assessed tree diversity and population structure in the homegarden land use of Mawsmai village, located on degraded karst landscape in East Khasi Hills, Meghalaya, India. The $1667 \mathrm{~m}^{2}$ sampled area of the village homegarden land use harbored 21 tree species. Tree density was reported to be 342 individuals $\mathrm{ha}^{-1}$. Most of the trees belonged to families that are common to the neighboring forest land. Homegarden land use was found to have the potential to conserve plant diversity on the degraded karst landscape along with improving food security.

KEYWORDS: Tree Diversity, Homegarden \& Karst
\end{abstract}

Received: May 02, 2017; Accepted: May 27, 2017; Published: Jun 07, 2017; Paper Id.: IJEEFUSJUN20174

\section{INTRODUCTION}

Homegardens are micro-environments possessing agronomic, genetic and cultural diversities (Watson \& Eyzaguirre, 2002). Kumar and Nair (2006) argued that homegarden agrobiodiversity is generally a result of socioeconomic and ecological factors, and farmers' choice, which is usually based on expected services. Production of food is considered to be the prime function of most of the homegardens (Nair, 2004). Imbruce (2007) considered homegardens to be a sort of "alternative agriculture" which have tight interconnections with conventional agriculture. Nevertheless, the structure and composition of homegardens help reduce resource deterioration which is usually a side effect of conventional agriculture (Nair, 2004). Homegardens can meet different farmers' needs without imposing negative impact on the resource base. Actually, they are likely to have positive impact on the resources besides improving various social, economic and ecological conditions (Torquebiau, 1992). Homegarden systems which are known for their marginal employed area and labor (Hoogerbrugge \& Fresco, 1993) are timetested systems (Nair, 2001). In determining the level of homegardens' sustainability, Ceccolini (2002) considered the sustainability to be directly proportional to the number of horizontal layers of vegetation, biodiversity and the deepness of traditional knowledge.

Asia harbors most of the homegardens in the world (Hoogerbrugge \& Fresco, 1993), which are seen to be common in all subtropical and tropical ecological regions (Fernandes \& Nair, 1986). In these regions, homegardens which usually contain tree, shrub, vines and herbaceous species (Nair, 2004) have changed the life of millions of people for hundreds of years through providing a means for subsistence and sometimes a mean for prosperity (Nair, 2001).

Karst habitats are fragile and very susceptible to perturbation (Walsh, 2000). Within the Indian subcontinent, the richest location with karst features is Meghalaya Plateau of Northeast India (Prokop, 2014). The 
objective of this study is to provide floristic description of plant communities of homegardens of Mawsmai village karst landscape, particularly for tree species $\geq 10 \mathrm{~cm} \mathrm{DBH}$ (diameter at breast height).

\section{MATERIALS AND METHODS}

\section{Study Area}

The study was conducted in Mawsmai village landscape, East Khasi Hills district, Meghalaya, north-eastern India (Figure 1). The village is located between $25^{\circ} 14^{\prime} 21.86^{\prime \prime}$ and $25^{\circ} 15^{\prime} 08.61^{\prime \prime}$ North latitudes and $91^{\circ} 43^{\prime} 05.45^{\prime \prime}$ and $91^{\circ} 43$ '57.02" East longitudes. The altitude is about $1200 \mathrm{~m}$ above sea level. The population is 475 in 98 households (Census of India, 2011). The climate is humid subtropical. The village encompasses two forests viz. Mawlong Syiem sacred forest and Ramjadong forest. There is no conventional agriculture in the village. The fragile and highly leached soil is developed over distinct limestone formation (Ramakrishnan, 1997). The vast grassland in the area is "sterile" system with armored surface layer and truncated soil 10 to $30 \mathrm{~cm}$ thick (Soja and Starkel, 2007).

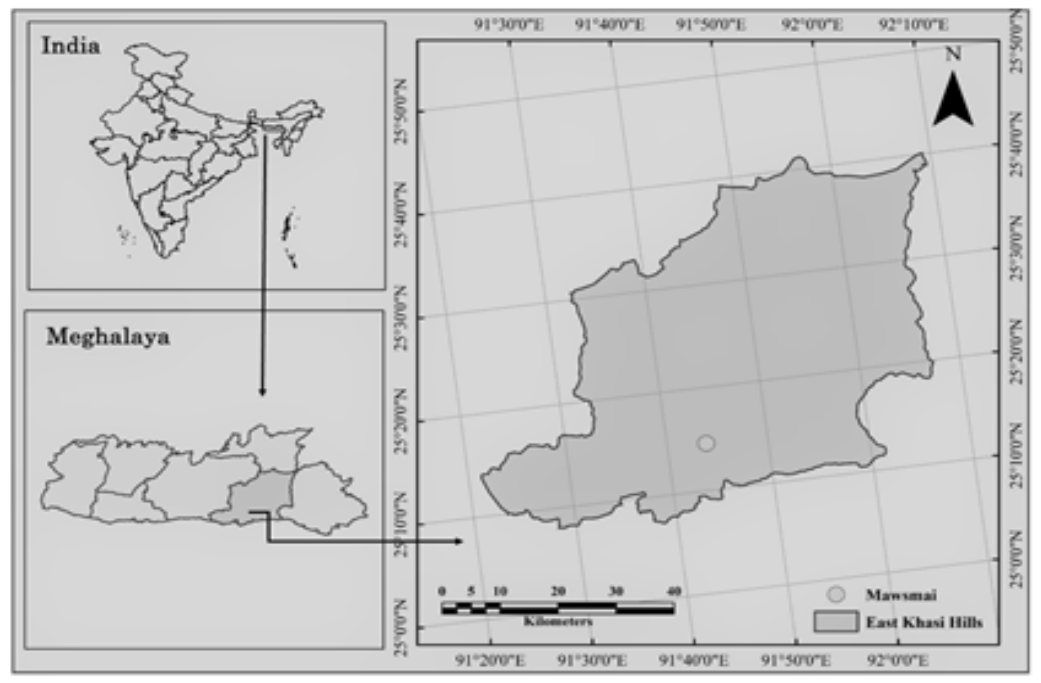

Figure 1: Location Map of the Study Area

\section{Data Collection and Analysis}

Field inventory was conducted between August 2013 and May 2014. Homegardens were identified in accordance with the characteristics stated in Hoogerbrugge and Fresco (1993), in which a homegarden represents a small, multilayered ecosystem with well-defined boundaries. Only fourteen out of the 25 gardens present in the village could be considered as homegardens. Grassland or civil structures surround the houses that do not have homegardens. The study adapted the Y-shaped sampling frame of Henry et al. (2009) for sampling village homegarden land use. From the center of the Y-shaped sampling frame, which was randomly located in the village settlement, three axes of $900 \mathrm{~m}$ each and forming $120^{\circ}$ with each other were demarcated. The dwellings of the village are concentrated in the southeastern part of the village making the gardens come within $300 \mathrm{~m}$ radius of the Y- shaped frame. In this study, all gardens intersected with the axes were identified. Eventually, 6 homegardens out of the 14 homegardens of the village were analyzed. Hence, the sampling intensity is $\approx 43 \%$. The sampled homegardens were analyzed in totality and each homegarden was considered as a plot of the homegarden land use of the village. The average area of a homegarden (excluding the area occupied by the house) was approximately $278 \mathrm{~m}^{2}$. 
Tree Diversity in Homegarden Land Use of Mawsmai Village

Each tree $\geq 10 \mathrm{~cm}$ DBH was measured for height and DBH and a herbarium was made. Species checklist for the shrubs and climbers was also prepared. The services of the plant species were reported. Botanical names were determined by consulting Botanical Survey of India, Shillong and relevant literature. The structural characterization of trees $\geq 10 \mathrm{~cm}$ DBH was investigated with regard to tree density (individuals $\left.\mathrm{ha}^{-1}\right)$, basal area $\left(\mathrm{m}^{2} \mathrm{ha}^{-1}\right)$, and DBH class distributions. Species richness was determined as the total number of species present in the homegarden land use. As appeared in Magurran (2004), Margalef index of species richness, Shannon's and Simpson's indices of diversity, and Pielou index of evenness were computed. Diversity indices were calculated for the homegarden land use of the village as per Wezel and Bender (2003) and Neelame gamet al. (2015). The indices were also calculated for each homegarden. Importance Value Index (IVI) of a species was calculated as per Curtis (1959) as cited in Saxena and Singh (1982)

\section{RESULTS}

The study reported 11 shrub species (10 genera and 8 families), 5 climber and epiphytic species ( 5 genera and 5 families), and 35 herbaceous species (31 genera and 19 families) in the $1667 \mathrm{~m}^{2}$ area representing homegarden land use of Mawsmai village Table 1.

Table 1: List of Shrub, Climbers, Epiphytic and Herb Species Identified in Homegarden Land Use of Mawsmai Village along with their Uses

\begin{tabular}{|c|c|c|}
\hline Shrub Species & Family & Use* \\
\hline Baliospermum calycinum Müll. Arg & Euphorbiaceae & Food \\
\hline Clerodendron colebrookianum Walp. & Verbenaceae & Medical, Food \\
\hline Duranta erecta L. & Verbenaceae & Fencing \\
\hline Hibiscus mutabilis L. & Malvaceae & Ornament \\
\hline Hibiscus pungens Roxb. & Malvaceae & Ornament \\
\hline Lantana camara $\mathrm{L}$. & Verbenaceae & Ornament \\
\hline Leucosceptrum canum Sm. & Lamiaceae & Naturally fencing \\
\hline Osbeckia crinita Benth. ex C.B. Clarke & Melastomataceae & Medical \\
\hline Rosa sp. & Rosaceae & Ornament \\
\hline Strobilanthes dimorphotricha Hance & Acanthaceae & - \\
\hline Tabernaemontana divaricata (L.) R.Br. ex Roem. \&Schult. & Apocynaceae & Ornamental, Fencing \\
\hline \multicolumn{3}{|l|}{ Climber and Epiphytic Species } \\
\hline Commelina benghalensis $\mathrm{L}$. & Commelinaceae & - \\
\hline Dendrobium chrysanthum Lindl. & Orchidaceae & Ornament \\
\hline Mikania micrantha (L.) Willd. & Asteraceae & - \\
\hline Passiflora edulis Sims. & Passifloraceae & Food \\
\hline Sechium edule (Jacq.) Sw. & Cucurbitaceae & Food \\
\hline \multicolumn{3}{|l|}{ Herb Species } \\
\hline Ageratina adenophora (Spreng.) R.M.King \& H.Rob & Asteraceae & - \\
\hline Allium cepa L. & Liliaceae & Food \\
\hline Allium sativum $\mathrm{L}$. & Liliaceae & Food \\
\hline Aloe vera (L.) Burm. f. & Liliaceae & Medical \\
\hline Alternanthera philoxeroides (Mart.) Griseb. & Amaranthaceae & - \\
\hline Beta vulgaris L. & Chenopodiaceae & Food \\
\hline Brassica juncea (L.) Czern. & Brassicaceae & Food \\
\hline Brassica oleracea $\mathrm{L}$. & Brassicaceae & Food \\
\hline Brassica sp. & Brassicaceae & - \\
\hline Centella asiatica $(\mathrm{L}$.$) Urban$ & Apiaceae & - \\
\hline Colocasia esculenta (L.) Schott & Araceae & - \\
\hline Coriandrum sativum $\mathrm{L}$. & Apiaceae & Food \\
\hline Daucus carota $\mathrm{L}$. & Apiaceae & Food \\
\hline Delphinium sp. & Ranunculaceae & - \\
\hline Dichrocephala integrifolia (L.f.) Kuntze & Asteraceae & - \\
\hline
\end{tabular}




\begin{tabular}{|c|c|c|}
\hline Drymaria cordata subsp. diandra (Blume) J.A.Duke & Caryophyllaceae & - \\
\hline Galinsoga parviflora Cav. & Asteraceae & - \\
\hline Hypoestes phyllostachya Baker & Acanthaceae & - \\
\hline Imperata $\mathrm{sp}$. & Poaceae & - \\
\hline Ligusticum striatum DC. & Apiaceae & - \\
\hline Lycopersicon esculentum Mill. & Solanaceae & Food \\
\hline Mecardonia procumbens (Mill.) Small & Plantaginaceae & - \\
\hline Mentha arvensis L. & Lamiaceae & Food, medical \\
\hline Oenanthe linearis Wall. ex DC. & Apiaceae & - \\
\hline Oxalis corniculata $\mathrm{L}$. & Oxalidaceae & Food \\
\hline Peranema cyatheoides D. Don & Dryopteridaceae & - \\
\hline Persicaria capitata (Buch.-Ham. ex D.Don) H.Gross & Polygonaceae & Medical \\
\hline Pisum sativum $\mathrm{L}$. & Fabaceae & Food \\
\hline Plantago asiatica subsp. erosa (Wall.) Z.Yu Li & Plantaginaceae & - \\
\hline Potentilla indica (Jacks.) Th.Wolf & Rosaceae & - \\
\hline Potentilla sundaica (Blume) Kuntze & Rosaceae & - \\
\hline Raphanus raphanistrum subsp. sativus (L.) Domin & Brassicaceae & - \\
\hline Rumex maritimus L. & Polygonaceae & - \\
\hline Solanum tuberosum L. & Solanaceae & Food \\
\hline Tagetes erecta $\mathrm{L}$. & Asteraceae & Ornament \\
\hline
\end{tabular}

Characteristics and diversity indices for the tree community of the homegarden land use are given in Table 2 . Tree density was reported to be $342 \pm 74$ trees $^{-1}$. The average number of trees in a homegarden in Mawsmai village was 9.50 \pm 2.05 . There was no strong correlation $(\mathrm{r}=0.32)$ between the number of individuals in a homegarden and the area of the homegarden. A total of 57 trees belonging to 21 species ( 2 identified to genus level) were encountered in the $1667 \mathrm{~m}^{2}$ area representing homegarden land use of Mawsmai village. The species belonged to 15 genera and 11 families. The average number of tree species in a homegarden in Mawsmai village was $5.17 \pm 1.08$. There was also no strong correlation $(r=0.45)$ between the number of tree species in a homegarden and the area of the homegarden. Based on diversity indices calculated for each homegarden independently, the average values of the indices were: Shannon diversity index $(1.29 \pm 0.29)$, Simpson dominance index $(0.39 \pm 0.13)$, and Pielous' evenness indices $(0.73 \pm 0.15)$, while Margalef's species richness index mean value was $1.73 \pm 0.42$. The study also reported the presence of Bambusa sp. (Poaceae) and Musa sp. (Musaceae) in the homegarden land use making the overall number of reported plant species to be 74 species.

Table 2: Characteristics and Diversity Indices for Trees $\geq 10 \mathrm{Cm}$ DBH of the Homegarden Land Use, Mawlong Syiem Sacred Forest and Ramjadong Forests of Mawsmai Village, Meghalaya, Northeast India

\begin{tabular}{|l|c|c|c|}
\hline \multicolumn{1}{|c|}{ Variables } & $\begin{array}{c}\text { Homegarden } \\
\text { Land Use }\end{array}$ & Ramjadong Forest & $\begin{array}{c}\text { Mawlong Syiem } \\
\text { Sacred Forest }\end{array}$ \\
\hline Area sampled $\left(\mathrm{m}^{2}\right)$ & 1667 & 3000 & 3000 \\
\hline Disturbance status & N/A & Moderately to highly disturbed & Mildly disturbed \\
\hline Density (trees ha $\left.{ }^{-1}\right)$ & 342 & 400 & 847 \\
\hline Basal area ${\left(\mathrm{m}^{2} \mathrm{ha}^{-1}\right)}^{\text {Average tree height (cm) }}$ & 12.21 & 15.25 & 32.31 \\
\hline Species richness (number of species) & 729 & 1194 & 1251 \\
\hline Magralef species richness index & 21 & 24 & 71 \\
\hline Shannon diversity index & 2.95 & 4.80 & 3.22 \\
\hline Pielou evenness index & 0.83 & 2.61 & 0.87 \\
\hline Simpson dominance index & 0.13 & 0.82 & 0.06 \\
\hline
\end{tabular}

Note: Data for Mawlong Syiem sacred forest and Ramjadong forests from Bdoor (2016). N/A: not applicable 
Tree class (10-20) was the most abundant with a share of $74 \%$ of total tree density. There was a sharp decline in tree density from lower to higher diameter classes with class 40-50 cm DBH as an exception, since no trees were reported in this class. Distribution of species richness in different tree DBH classes revealed the presence of relatively high richness (17 species, $81 \%$ of the species) in the $10-20 \mathrm{~cm}$ DBH class (Figure 2).

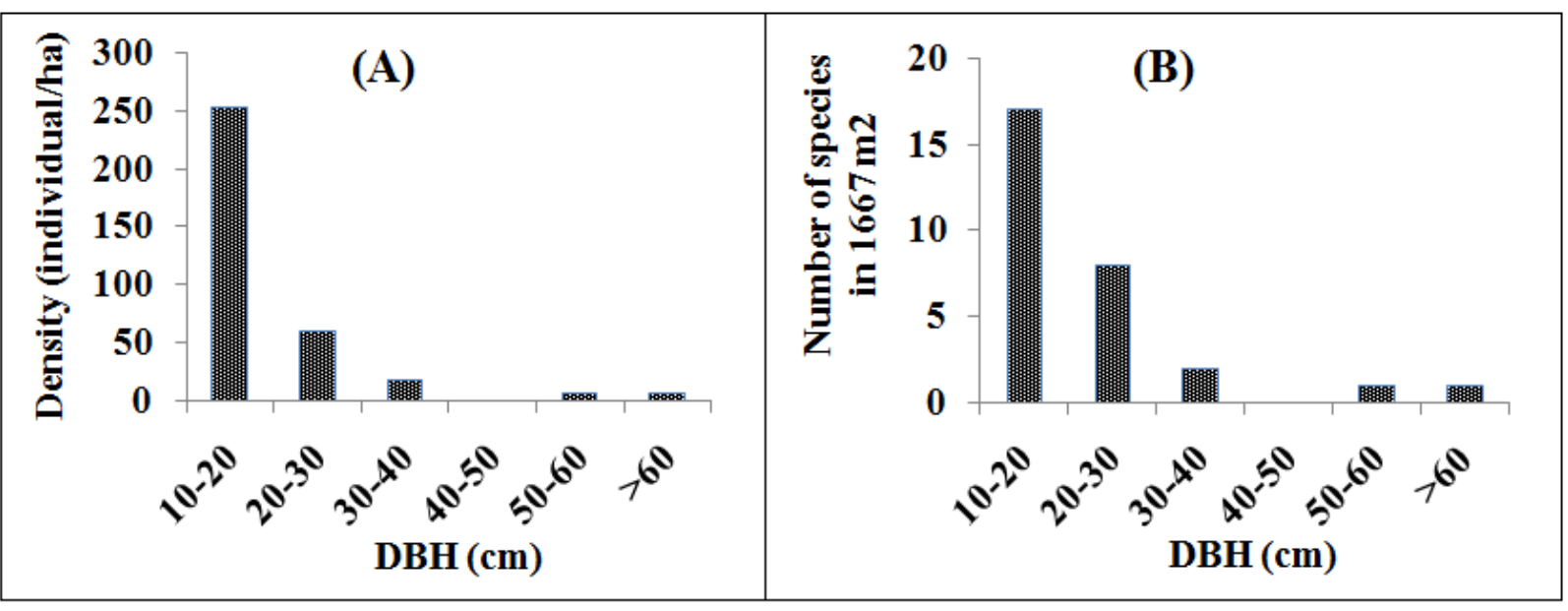

Figure 2: Tree Density (A) and Tree Species Richness (B) in Different Tree Diameter Classes in the Homegarden Land Use of Mawsmai Village, Meghalaya, Northeast India

The contribution of different tree diameter classes in basal area shows that in the homegarden land use, young trees class 10-20 cm DBH accounted for the largest share of basal area (39\%) (Figure 3).

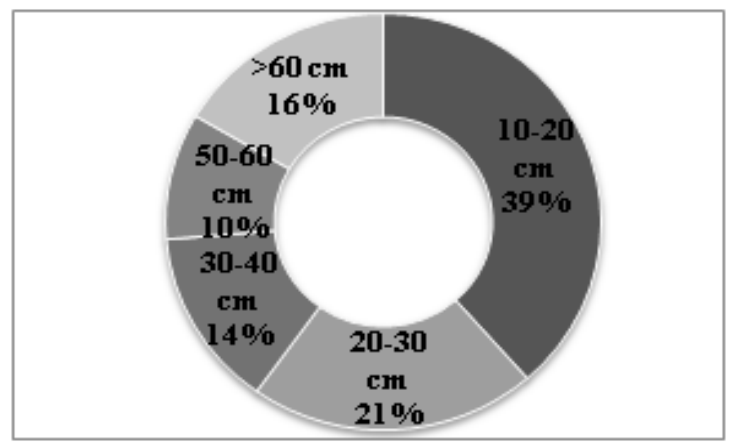

Figure 3: Tree Diameter Classes' Contribution in Basal Area in Homegarden Land Use of Mawsmai Village, Meghalaya, Northeast India

The most dominant species in terms of importance value in the homegarden land use was Ligustrum confusum (IVI: 61.7). The second dominant species was Wendlandia budleioides (IVI: 47.2) (Table 3). With 4 species, Rosaceae was the dominant family in Mawsmai homegarden land use with regard to species richness. Euphorbiaceae, Moraceae, and Myrtaceae were represented by 3 species each. Six families were mono specific. Each having 78 individuals ha ${ }^{-1}$, Oleaceaeand Rubiaceae was the dominant families based on density in Mawsmai homegarden land use.

Out of the 57 trees sampled in the homegardens, 55 trees (96.5\%) were part of homegarden fencing and marking out boundaries. About $71 \%$ of the reported tree species had food production service. Although the species may have medical usage, the knowledge of the medical use was limited to few elderly individuals. Trees, particularly younger trees, were not planted or kept solely for the medical use. No tree species was reported to be planted for fuel wood. 
Table 3: Density (Individuals $\left.\mathrm{Ha}^{-1}\right)$, Basal Area $\left(\mathrm{M}^{2} \mathrm{Ha}^{-1}\right)$, Importance Value Index (IVI) and Uses of Tree Species $(\geq 10 \mathrm{Cm}$ DBH) of Homegarden Land Use in Mawsmai Village

\begin{tabular}{|c|c|c|c|c|c|}
\hline Species & Family & Density & $\begin{array}{c}\text { Basal } \\
\text { area }\end{array}$ & IVI & Use \\
\hline Baccaurea sapida (Roxb.) Muell-Arg & Euphorbiaceae & 6 & 0.69 & 10.6 & Fruits, Fencing \\
\hline Baccaurea sp. & Euphorbiaceae & 6 & 0.22 & 6.8 & Fruits, Fencing \\
\hline Callicarpa arborea Roxb. & Lamiaceae & 6 & 0.16 & 6.3 & Fencing \\
\hline Citrus aurantiumL. & Rutaceae & 12 & 0.21 & 11.7 & Fruits, Fencing \\
\hline Citrus sp. & Rutaceae & 6 & 0.10 & 5.8 & Fruits \\
\hline Ficus glaberrima Blume & Moraceae & 6 & 0.14 & 6.2 & Fruits, Fencing \\
\hline Ficus racemosa $\mathrm{L}$. & Moraceae & 6 & 0.09 & 5.7 & Fruits, Fencing \\
\hline Grevillea robusta A.Cunn. ex R.Br. & Proteaceae & 6 & 0.10 & 5.8 & Ornament, Fencing \\
\hline Ligustrum confusum Decne. & Oleaceae & 78 & 3.17 & 61.7 & Fencing \\
\hline Morus australis Poir. & Moraceae & 6 & 0.09 & 5.7 & Fruits, Fencing \\
\hline Pyrus communis L. & Rosaceae & 6 & 0.25 & 7.0 & Fruits, Fencing \\
\hline Pyrus pashia Buch.-Ham. ex D.Don & Rosaceae & 18 & 0.86 & 15.5 & Fruits, Fencing \\
\hline Syzygium cumini (L.) Skeels & Myrtaceae & 12 & 0.25 & 8.8 & Fruits, Fencing \\
\hline Syzygium tetragonum (Wight) Wall. exWalp. & Myrtaceae & 6 & 0.18 & 6.5 & Fruits, Fencing \\
\hline Thuja occidentalis L. & Cupressaceae & 12 & 0.37 & 9.7 & Ornament, Fencing \\
\hline Wendlandia budleioides Wall. ex Wight \&Arn. & Rubiaceae & 78 & 1.80 & 47.2 & Ornament, Fencing \\
\hline
\end{tabular}

\section{DISCUSSIONS}

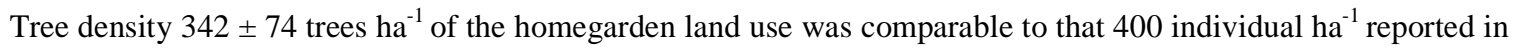
Bdoor (2016) for the disturbed non-sacred Ramjadong forest located on the same karstic landscape (Table 2). There was no strong correlation between tree density and the area of the homegardens; and neither was there strong correlation between tree species richness and the area of the homegarden. This indicates the central role of management in determining tree density and tree species composition in the homegardens. Margalef species richness index average value (tree $\geq 10 \mathrm{~cm}$ $\mathrm{DBH})$ of the present study $(1.73 \pm 0.42)$ is within Margalef index range $(0.66-4.92)$ for tree species $>4.8 \mathrm{~cm} \mathrm{DBH}$ reported by Das and Das (2015) for homegardens in Khasi villages of Barak Valley, Assam.

Shannon index average value for the homegardens reported in the present study is comparable to Shannon index average value 1.21 reported by Peyre et al. (2006) for tree/shrub species for homegardens $(0.1$ ha to 0.2 ha; $n=4)$ in Palghat district, Kerala, India. Shannon index value reported in the present study is markedly higher than Shannon index value 0.74 reported by Wezel and Bender (2003) for fruit tree species in homegardens $(n=8)$ in El Recreo village, which is located in area associated with natural submontane evergreen rain forest, Cuba. For the south-central highlands of Ethiopia, Toler aet al. (2008) reported that Shannon and Simpson diversity indices for the forest land were higher than that for homegarden land use. The researcher reasoned their result by species' uniform distribution in natural forest in comparison to homegardens. On the other hand, Gajaseni and Gajaseni (1999) stated that the value of Shannon index (1.9 to 2.7) reported in their study for plant species in homegardens $(n=4)$ in Chao Phraya Basin, Thailand was close to the range of Shannon index values reported for a local forest. Similarly, Shannon diversity index for Mawsmai homegarden land use calculated in the present study to be 2.52 is comparable to Shannon index value 2.61 for the nearby Ramjadong forest (Table 2). The relatively high Shannon index value for the homegarden land use could be further considered as indication that Mawsmai homegarden land use harbours substantial tree diversity. Through comparing tree families reported in the present study with that reported in Bdoor (2016), six tree families in the homegarden land use $(\approx 55 \%$ of total number of tree families) 
Tree Diversity in Homegarden Land Use of Mawsmai Village

were found to be common to the forest land of Mawsmai village. The common families accounted for $\approx 79 \%$ of the number of tree individuals in the homegarden land use indicating possible impact of proximity to forest land on tree planting preferences. This high representation of forest tree families in the homegardens also indicates the potential of homegarden land use to conserve tree diversity in this karstic landscape.

The total number of plant species reported in the present study (74 plant species) is more than the 47 plant species reported in Kala (2010) for the homegardens in 10 villages in buffer zone of Pachmarhi Biosphere Reserve, Madhya Pradesh, India. The herbaceous species in the homegardens are combination of naturally occurring herbs and these planted for food production or medical services. Shrubs and herbs are included in the medical use rather than tree species which are planted for other reasons, mainly food production. Using the trees as biological fence was rather a preferred way of distributing fruits producing trees and ornamental trees in the homegardens. Gymnosperm us tree Thuja occidentalis (Cupressaceae) was reported in the homegarden land use. The species was planted for beautification as it resembles Christmas tree. This reflects a way in which religion may have an influence on tree composition of homegardens. The presence of considerable proportion of plant species that have food production service indicates that homegardening is improving food security in this karst landscape by reducing the dependency of the households on food products from outside areas.

Since homegardens were established on degraded grassland, adding manure as well as duff from the forests to the homegardens was a common practice in Mawsmai village. Hence, regardless of the shallow soil of Mawsmai karst landscape, soil management enabled homegarden land use to harbor substantial number of plant species making homegardening a viable option to conserve plant diversity on this karst landscape.

Although Khasi tribe was seen to be tightly attached to Khasi ethnicity, there were restrictions for people from out of the village to settle in it even if they were Khasi. This is due to the community ownership system in which properties are not transferable without the approval of Elaka, the elected administrative unit. For homegardens in Indonesian villages Kehlenbeck (2007) reported higher diversity index values in local villages than in migrant villages. Therefore, the absence of immigrants might have supported plant diversity of the homegardens. However, immigrants were found to introduce new skills in managing homegardens and making them more fruitful (Imbruce, 2007). Therefore, the absence of immigration may have affected the development of homegarden land use which is reflected in the number of homegardens in the village. It was noticed that the low number of homegardens in the village was even higher than that reported in other studies. For example, while studying village ecosystem function of a Khasi village and a Nepali village in the Khasi hills of Meghalaya, Patnaik and Ramakrishnan (1989) reported the absence of homegarden land use in the Khasi village. While evaluating the economic and ecological efficiency of land use systems for four communities (the Garos, Khasis, Mikirs and Nepalis) in the Khasi hills of Meghalaya, Maikhuri and Ramakrishnan (1990) reported the presence of three homegardens only in Mikirs village which were analyzed and found to be of highly efficient in energy and economic terms. Additionally, having evolved along divergent lines, indigenous agro ecosystems were found to be highly site specific systems (Chandra et al., 2011). The values obtained in this study are for homegardens i.e. multi-storied well defined gardens. These values reflect the potential of the karst landscape in harboring species-rich agro-ecosystems. 


\section{CONCLUSIONS}

This study provided an account of tree species diversity in Mawsmai homegarden land use. The homegarden land use is seen to have the ability to conserve plant diversity on the degraded karst landscape. Besides, homegardens also provided several services to the households. Encouraging homegardening strategy in this populated karst landscape would be beneficial.

\section{ACKNOWLEDGEMENTS}

The author sincerely thanks Prof. K. G. Saxena of the School of Environmental Sciences, Jawaharlal Nehru University, and New Delhi for his insightful guidance. Dr. A. A. Mao, Head of Office, Eastern Regional Centre, Botanical Survey of India is thankfully acknowledged for the facilities and support provided during this study. The author is grateful to the people of the Mawsmai village for their kind hospitality.

\section{REFERENCES}

1. Bdoor, B. S. (2016). Tree Diversity and Population Structure in Sacred and Non-sacred Forests on Karst Landscape in Meghalaya, Northeast, India. Environment \& We: An International Journal of Science and Technology, 11 (1-2) 17-32

2. Ceccolini, L. (2002). The homegardens of Soqotra island, Yemen: an example of agro forestry approach to multiple land-use in an isolated location. A groforestry systems, 56(2), 107-115.

3. Census of India (2011). Mawsmai village census data. Retrieved from http://www.census2011.co.in/data/village/278812mawsmai-meghalaya.html

4. Chandra, A., Saradhi, P. P., Maikhuri, R. K., Saxena, K. G., \& Rao, K. S. (2011). Traditional agrodiversity management: A case study of central himalayan village ecosystem. Journal of Mountain Science, 8(1), 62-74.

5. Das, T., \& Das, A. K. (2015). Conservation of Plant Diversity in Rural Homegardens with Cultural and Geographical Variation in Three Districts of Barak Valley, Northeast Indial. Economic Botany, 69(1), 57-71.

6. Fernandes, E. M., \& Nair, P. R. (1986). An evaluation of the structure and function of tropical homegardens. Agricultural Systems, 21, 279-310.

7. Gajaseni, J., \& Gajaseni, N. (1999). Ecological rationalities of the traditional home garden system in the Chao Phraya Basin, Thailand. A groforestry Systems, 46(1), 3-23.

8. Henry, M., Tittonell, P., Manlay, R. J., Bernoux, M., Albrecht, A., \& Vanlauwe, B. (2009). Biodiversity, carbon stocks and sequestration potential in above-ground biomass in smallholder farming systems of western Kenya. Agriculture, Ecosystems \& Environment, 129(1), 238-252.

9. Hoogerbrugge, I. D., \& Fresco, L. (1993). Homegarden systems: agricultural characteristics and challenges. Sustainable Agriculture Programme, International Institute for Environment and Development.

10. Imbruce, V. (2007). Bringing Southeast Asia to the Southeast United States: new forms of alternative agriculture in Homestead, Florida. Agriculture and Human Values, 24(1), 41-59.

11. Kala, C. P. (2010). Home gardens and management of key species in the Pachmarhi Biosphere Reserve of India. Journal of Biodiversity, 1(2), 111-117.

12. Kehlenbeck, K. (2007). Rural homegardens in Central Sulawesi, Indonesia: an example for a sustainable agro-ecosystem. Doctoral Disseration. Faculty of Agriculture. University of Gottingen, Germany. 
Tree Diversity in Homegarden Land Use of Mawsmai Village

13. Kumar, B. M., \& Nair, P. R. (Eds.). (2006). Tropical homegardens: a time-tested example of sustainable agroforestry (Vol. 3). Springer.

14. Magurran, A. E. (2004). Measuring biological diversity. Malden, Ma.: Blackwell Pub.

15. Maikhuri, R. K., \& Ramakrishnan, P. S. (1990). Ecological analysis of a cluster of villages emphasising land use of different tribes in Meghalaya in north-east India. Agriculture, ecosystems \& environment, 31(1), 17-37.

16. Nair, P. R. (2001). Do tropical homegardens elude science, or is it the other way around?. Agro forestry systems, 53(2), 239245.

17. Nair, P. R. (2004). Tropical home gardens. In The Over story Book: Cultivating Connections with Trees, ed. Elevitch, C.R., 2, pp: 5-7 Permanent Agriculture Resources, USA.

18. Neelamegam, R., Roselin, S., Mary Anishal Priyanka, A., \& Mathevan Pillai, V. (2015) Diversity Indices of Home Garden Plants in Rural and Urban Areas in Kanyakumari District, Tamil Nadu, India.Scholars Academic Journal of Biosciences, 3(9), $752-761$.

19. Patnaik, S., \& Ramakrishnan, P. S. (1989). Comparative study of energy flow through village ecosystems of two co-existing communities (the Khasis and the Nepalis) of Meghalaya in north-east India. Agricultural systems, 30(3), 245-267.

20. Peyre, A., Guidal, A., Wiersum, K. F., \&Bongers, F. J. J. M. (2006). Dynamics of homegarden structure and function in Kerala, India. Agroforestry Systems, 66(2), 101-115.

21. Prokop, P. (2014). The Meghalaya Plateau: Landscapes in the Abode of the Clouds. In Landscapes and Landforms of India (pp. 173-180). Springer Netherlands.

22. Ramakrishnan, P. S. (1997). Unity in Diversity. Ecodecision-Montreal-, 56-60.

23. Saxena, A. K., \& Singh, J. S. (1982). A phytosociological analysis of woody species in forest communities of a part of Kumaun Himalaya. Vegetatio, 50(1), 3-22.

24. Soja, R., \&Starkel, L. (2007). Extreme rainfalls in Eastern Himalaya and southern slope of Meghalaya Plateau and their geomorphologic impacts. Geomorphology, 84(3), 170-180.

25. Tolera, M., Asfaw, Z., Lemenih, M., \&Karltun, E. (2008). Woody species diversity in a changing landscape in the south-central highlands of Ethiopia. Agriculture, ecosystems \& environment, 128(1), 52-58.

26. Torquebiau, E. (1992). Are tropical agroforestry home gardens sustainable?. Agriculture, ecosystems \& environment, 41(2), 189-207.

27. Walsh, S. J. (2000). Conservation of aquatic karst biotas: shedding light on troubled waters, essay 15. pp 106-108, In: Abell, R. A., Olson, D. M., Dinerstein, E., Hurley, P. T., Diggs, J. T., Eichbaum, W., Walters, S., Wettengel, W., Allnutt, T., Loucks, C. J. \& Hedao, P., Freshwater Ecoregions of North America: A conservagtionAssesssment, Island Press, Washington, D.C.

28. Watson, J. W., \&Eyzaguirre, P. B. (Eds.). (2002). Home gardens and in situ conservation of plant genetic resources in farming systems. Bioversity International.

29. Wezel, A., \& Bender, S. (2003). Plant species diversity of homegardens of Cuba and its significance for household food supply. Agroforestry systems, 57(1), 39-49. 
